\title{
GREAT HORNED OWLS LOCKED IN MORTAL COMBAT
}

CHRISTIAN ARTUSO, University of Manitoba, Department of Environment and Geography, Winnipeg, MB R2T 2N2, E-mail: <chartuso@gmail.com>, and RANDY MOOI, The Manitoba Museum, 190 Rupert Avenue, Winnipeg, MB R3B 0N2, Email:<rmooi@manitobamuseum.ca>

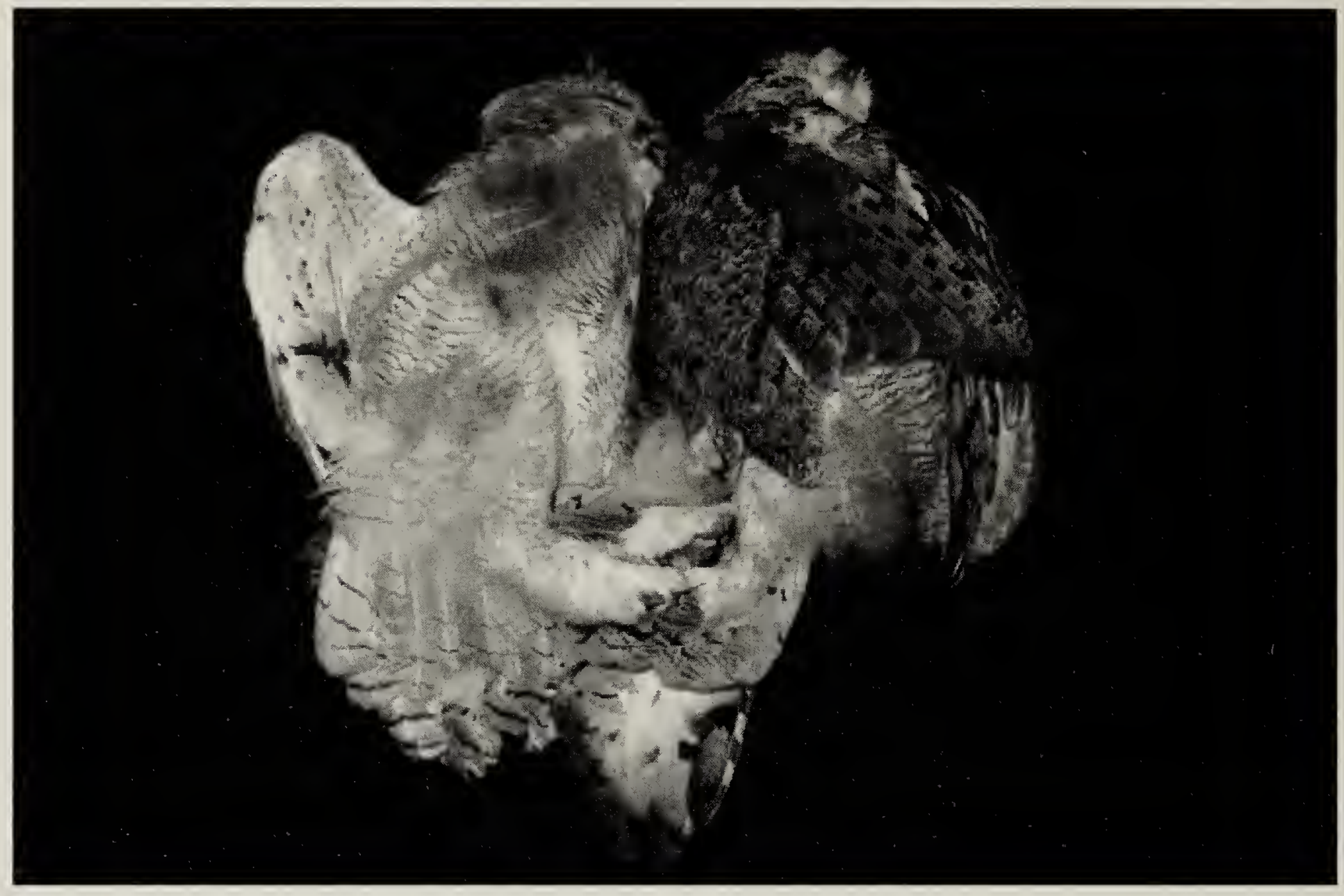

Figure 1. The two Great Horned Owls as they were found.

R. Mooi

In early January 2005, two dead Great Horned Owls were found in a hay barn near Cartwright, Manitoba. (Figure 1). The talon of the inner toe of the larger of the two owls had pierced the footpad of the other (Figure 2). The larger owl was a female, as determined later by internal inspection (Manitoba Museum specimen 1.25251), and the other was a male (Manitoba Museum specimen 1.25252). It appears that the owls had been unable to extricate themselves from this position, leading to their eventual demise. Both owls had signs of bleeding about the bill, and the male suffered a wound to the lower neck such that some breast feathers were matted with blood.
Great Horned Owls are known occasionally to be aggressive toward each other. ${ }^{2}$ On August $15^{\text {th }} 2007$, Christian Artuso observed two recently fledged Great Horned Owls apparently competing for position on an open perch, resulting in one gripping the other's foot for a period of approximately 90 seconds (Figure 3 ), demonstrating how the feet may be used in such interactions.

Inspection of molt limits of the two owls found uniformly fresh remiges and rectrices, consistent with the hatch year/ second year age class. ${ }^{5}$ Since these owls were found dead in January, both were likely less than one year old. The gonads of neither of 


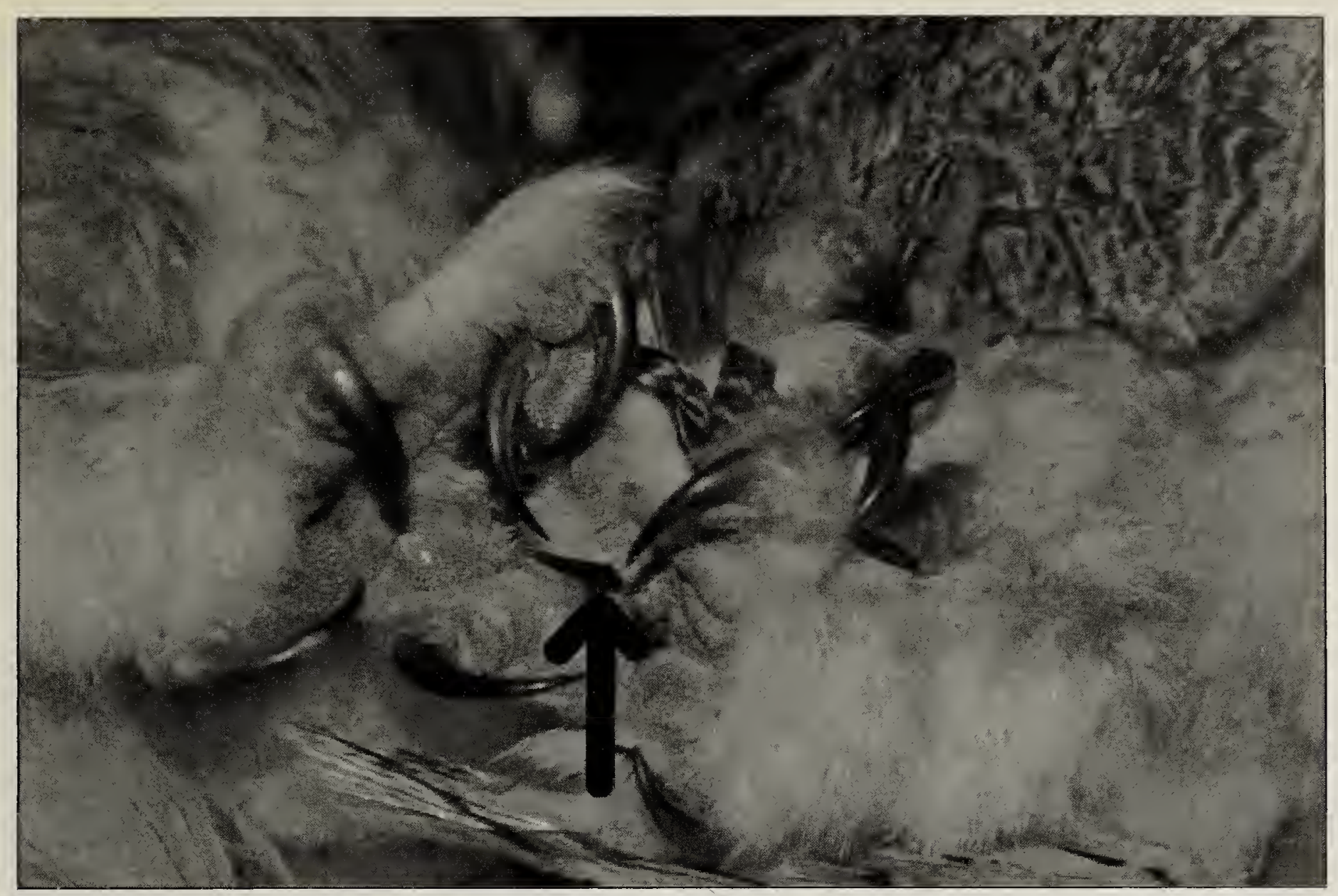

Figure 2. View of the underside of the feet of two Great Horned Owls showing the talon (at arrow) of the female (left) protruding through the foot pad of the male (right).

C.Artuso

these individuals were large enough to suggest the onset of breeding (length of ovary: $14.5 \mathrm{~mm}$, length of left testis: $4.5 \mathrm{~mm}$ ). The two owls described here may have been involved in a territorial dispute in advance of the breeding season, e.g. a paired female driving off a floater male. Great Horned Owls typically begin the breeding cycle in late February - March in southern Manitoba, rarely as early as mid-January in suburban areas, ${ }^{1}$ although pair bonding and territorial defense likely occurs well before clutch initiation. ${ }^{2}$

Alternatively, this incident could have occurred as a result of non-breeding individuals competing for a food resource-rodents living in the hay barn where the owls were found. The gizzards of both of these owls contained the remains of North American Deermice. Cannibalistic predation is unlikely, especially given the relatively small difference in size and weight (female: total length: $520 \mathrm{~mm}$, wing chord: $378 \mathrm{~mm}$, tail: $225 \mathrm{~mm}$, foot pad: $72 \mathrm{~mm}, 1.2 \mathrm{~kg}$; male: total length: $512 \mathrm{~mm}$, wing chord: $342 \mathrm{~mm}$, tail: $205 \mathrm{~mm}$, foot pad: $62 \mathrm{~mm}$, $1.14 \mathrm{~kg})$. Cannibalism among Great Horned Owls has been reported, ${ }^{4}$ and Great Horned owls may kill conspecifics, although direct evidence of this is still lacking. ${ }^{7}$

The tendon-locking mechanism (TLM) that apparently kept these two birds together occurs in many bird families. It is used in perching, perching while sleeping, climbing, hanging, and swimming. ${ }^{6}$ Owl feet are especially strong, probably an adaptation to their sit-and-pounce hunting style which necessitates incapacitating and holding onto prey on first strike (as opposed to the weaker grip of diurnal raptors which typically employ pursuit techniques). ${ }^{8}$ A force of $13 \mathrm{~kg}$ is required to open the talons of a Great Horned Owl. ${ }^{3}$ It is 


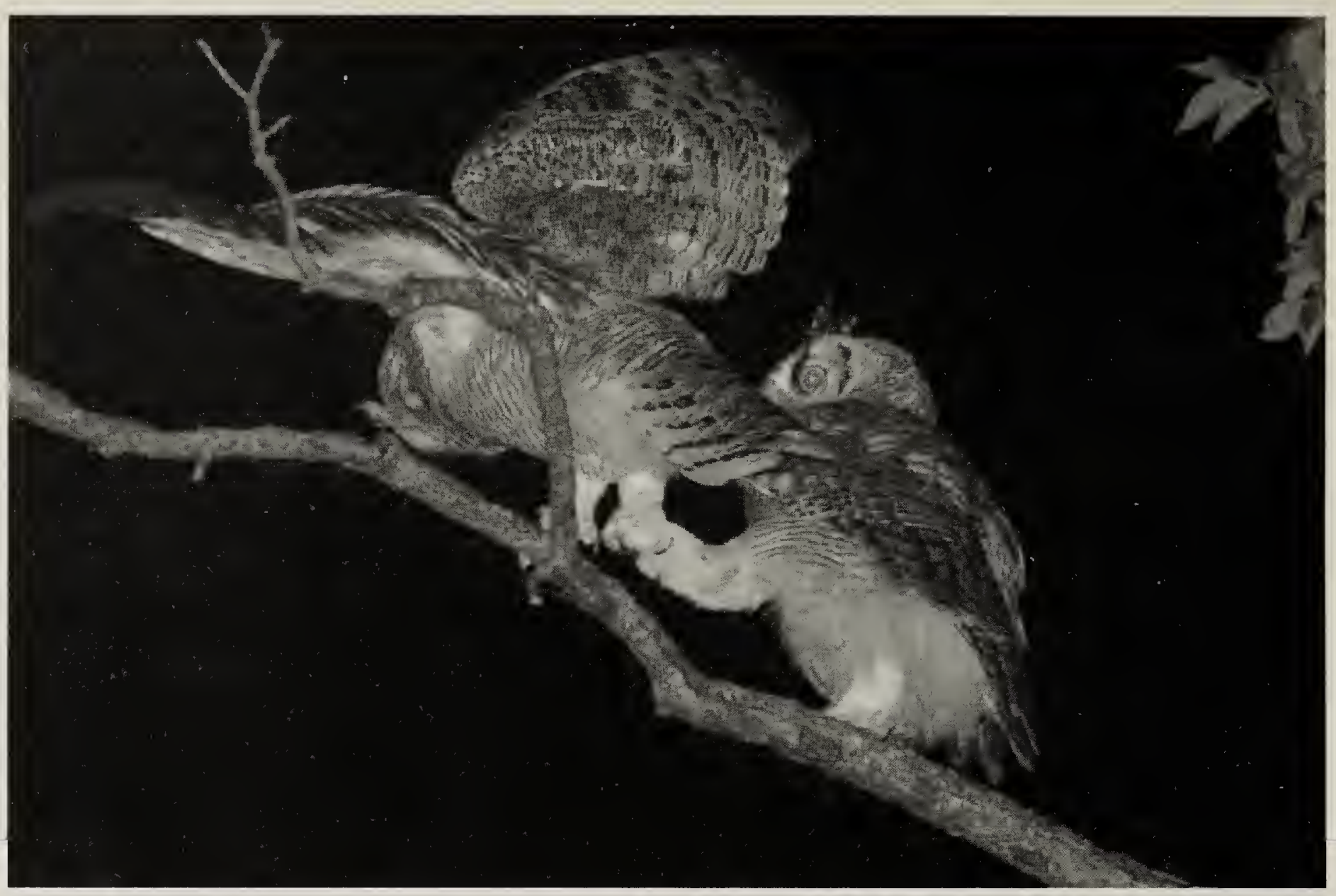

Figure 3. Two recently fledged sibling Great Horned Owls interacting, 15 August 2007. Note the way the bird on the left is gripping the other's foot.

C. Artuso

possible that as the male tried to withdraw his foot from the female's grip, she responded by pulling back, which would automatically lock the talons in the flexed position. Banders who have experienced the unrelenting power of a raptor's grasp under duress know that it is often necessary to straighten the leg to release the tension in the muscles before removing the talons one at a time (Diego Sustaita, pers. comm.).

\section{Acknowledgements}

We are grateful to Hal Haight for donating these Great Horned Owl carcasses to the museum and to Diego Sustaita for assistance in the preparation of this manuscript.

1. ARTUSO, C. 2007. January initiation of suburban Great Horned Owl nests in Manitoba. Blue Jay 65: 26-33.
2. HOUSTON, C. S., D. G. SMITH, and C. ROHNER. 1998. Great Horned Owl (Bubo virginianus). In The Birds of North America, No. 372 (A. Poole and F. Gill, Eds.). The Birds of North America, Inc., Philadelphia, PA.

3. MARTI, C. D. 1974. Feeding ecology of four sympatric owls. Condor 76: 45-61.

4. MILLARD, J. B. 1978. Cannibalism by an adult Great Horned Owl. Wilson Bulletin 90: 449.

5. PYLE, P. 1997. Identification Guide to North American Birds: Part I Columbidae to Ploceidae. Slate Creek Press, Bolinas, California, U.S.A.

6. QUINN, T. and J. BAUMEL. 1990. The digital tendon locking mechanism of the avian foot (Aves). Zoomorphology 109: 281-293.

7. ROHNER, C. 1997. Non-territorial 'floaters' in Great Horned Owls: space use during a cyclic peak of snowshoe hares. Animal Behavior 53: 901912.

8. WARD, A. B., P. D. WEIGL, and R. M. CONROY. 2002. Functional morphology of raptor hindlimbs: Implications for resource partitioning. The Auk 119: 1052-1063. 